Article

\title{
Conflicts over GMOs and their Contribution to Food Democracy
}

\author{
Beate Friedrich ${ }^{1, *}$, Sarah Hackfort ${ }^{2}$, Miriam Boyer ${ }^{3}$ and Daniela Gottschlich ${ }^{4}$ \\ ${ }^{1}$ Institute of Sustainability Governance, Leuphana University of Lüneburg, 21335 Lüneburg, Germany; \\ E-Mail: beate.friedrich@uni.leuphana.de \\ ${ }^{2}$ IZT_Institute for Future Studies and Technology Assessment, 14129 Berlin, Germany; E-Mail: s.hackfort@izt.de \\ ${ }^{3}$ Department of Agriculture and Food Policy, Faculty of Life Sciences, Humboldt-Universität zu Berlin, 10099 Berlin, \\ Germany; E-Mail: miriam.boyer@hu-berlin.de \\ ${ }^{4}$ Institute for Diversity, Nature, Gender and Sustainability (diversu e.V.), 21339 Lüneburg, Germany; \\ E-Mail: gottschlich@diversu.org \\ * Corresponding author
}

Submitted: 15 March 2019 | Accepted: 31 July 2019 | Published: 28 October 2019

\begin{abstract}
The use of genetically modified organisms (GMOs) embodies a specific vision of agricultural systems that is highly controversial. The article focuses on how conflicts over GMOs contribute towards food democracy. Food democracy is defined as the possibility for all social groups to participate in, negotiate and struggle over how societies organize agricultural production, thereby ensuring that food systems fulfil the needs of people and sustain (re)productive nature into the future. EU agricultural policy envisages the coexistence of agricultural and food systems with and without GMOs. This policy, which on the surface appears to be a means of avoiding conflict, has in fact exacerbated conflict, while creating obstacles to the development of food democracy. By contrast, empirical analysis of movements against GMOs in Germany and Poland shows how they create pathways towards participation in the food system and the creation of alternative agricultural futures, thereby contributing to a democratization of food systems and thus of society-nature relations. Today, as products of new breeding techniques such as genome editing are being released, these movements are gaining new relevance.
\end{abstract}

\section{Keywords}

agriculture; conflicts; food democracy; genetically modified organisms; new breeding techniques; social ecology; social movements; society-nature relations

\section{Issue}

This article is part of the issue "New Perspectives on Food Democracy" edited by Basil Bornemann (University of Basel, Switzerland) and Sabine Weiland (Université Catholique de Lille, France).

(C) 2019 by the authors; licensee Cogitatio (Lisbon, Portugal). This article is licensed under a Creative Commons Attribution 4.0 International License (CC BY).

\section{Introduction}

Since the 1970s, and even more since the early 2000s, various socio-environmental struggles in policy fields such as climate, energy, mobility and, not least, food can be identified as part of a new movement concerned with the democratization of society-nature relations. Struggles against the implementation of genetically modified plants and animals in agriculture are an essential part of the movement for food democracy, in which "agricultural policy is perceived as a citizens' affair" (Haerlin, 2013, p. 47, authors' translation).
Conflicts over food relations are processes in which participation in policy making and forms of agricultural production and consumption are struggled over and (temporarily) decided. In this study, we focus on conflicts over genetically modified organisms (GMOs) in agriculture and analyse their contribution to food democracy. The application of genetic engineering has given rise to a large number of social conflicts, from scientific debates regarding the safety and appropriate use of the technology, to disputes among agricultural producers and conflicts involving consumers (cf. Friedrich, 2015; Levidow \& Carr, 2010). In addition to highlighting key is- 
sues raised by the development of GMOs these conflicts raise broader questions: regarding what kind of agriculture is desirable, what kinds of food should be produced, what kinds of technology should be used, and who should have access to and control over these technologies, among others. Moreover, laws and other policies intended to resolve these disputes themselves become the object of new conflicts (Gottschlich, Sulmowski, \& Friedrich, 2017). Our research question is: How do conflicts over GMOs contribute to a democratization of society-nature relations? How the way these conflicts are dealt with over time shapes specific constellations of society-nature relations that can also be more or less democratic, in the sense that participation becomes more or less possible or that conflicts give rise to outcomes that are more or less sustainable. In the empirical examples below, the focus is specifically on how and to what extent such conflicts enable food democracy. The analytical findings of this study not only shed light on the constitution of food democracy, but can also be helpful for understanding how conflicts in other policy fields, such as energy or mobility, contribute to a democratization of society-nature relations.

After outlining our conceptual framework (Section 2), we describe the context for our empirical case study of the movements against GMOs in Germany and Poland and present the results (Section 3). This is followed by a discussion of our findings regarding the contribution of conflicts surrounding GMOs to food democracy (Section 4). The final section summarizes our argument and considers new issues raised by the further development of GMOs and new breeding techniques (Section 5).

\section{Conceptual Framework: Substantive and Procedural Dimensions of Food Democracy from a Critical-Emancipatory Perspective}

Food democracy can be defined as the possibility for all social groups to participate in, negotiate and struggle over how societies organize agricultural production, thereby ensuring that food systems fulfil the needs of people and sustain (re)productive nature into the future. We follow Hassanein (2003, p. 83), who argues that "food democracy ideally means that all members of an agrofood system have equal and effective opportunities for participation in shaping that system, as well as knowledge about the relevant alternative ways of designing and operating the system." Hassanein $(2003$, p. 85$)$ considers food democracy as a pragmatic device for incremental change towards a radical transformation of the food system and places active participation and political engagement (e.g., social movements that exert pressure on existing social structures) at the core of food democracy. Similarly, Petetin maintains that food democracy is about empowering people to influence food systems, leading towards "a more sustainable and just society where the public can actively participate in the decision-making process for foods" (Petetin, 2016, p. 1).
While recognizing the importance of participation, in this study we adopt a broader definition of food democracy. We draw on Fraser's (2009) work on democracy and justice to differentiate between: (1) the procedural dimension of food democracy, i.e., participatory processes leading to the creation of spaces for debate, negotiation and protest; and (2) the substantive dimension of food democracy, i.e., the outcomes and impacts of specific modes of agricultural production.

With regard to the procedural dimension, we agree with Barber (1984/2003) that direct participation is imperative for a 'strong democracy' that goes beyond mere representation (cf. Behringer \& Feindt, 2019). Participation may take various forms: from taking part in institutionalized negotiation processes to resistance and civil disobedience. It may also take place on different levels, giving rise to social change through top-down development of policies and associated legislation, or through bottom-up engagement in grassroots activities, including boycotts and protests. Participation is structured by other social relations that determine access to resources or influence the emergence of social inequalities, including class and gender (Fraser, 2009). This emphasis on participation encompasses important aspects of the food sovereignty debate (Carlson \& Chapell, 2015). As a "social movement" (Petetin, 2016, p. 1) and "a set of demands from below" (Lang, 1999, p. 218), the political movement for food sovereignty emerged out of struggles to counter neoliberal trade, distribution, land-use and resource regimes that are asymmetrical and limit or exclude large groups of people from participation in shaping the future of food systems (McMichael, 2014). The availability of spaces for public debate and negotiation, for protest and resistance, also constitutes an important condition for food democracy. Demands for both food democracy and food sovereignty go beyond 'voting with your fork,' recognising that achieving sustainable agricultural systems will require structural changes in power relations, decision-making, and in "how we do democracy" (Carlson \& Chapell, 2015, p. 7, emphasis in original).

At the same time, we maintain that substantive outcomes of the food system are equally important for food democracy. One important substantive outcome identified in debates surrounding food sovereignty and democracy is sustainability (Hassanein, 2003, p. 78; Loos et al., 2014; Petetin, 2016, p. 2; Wittman, 2011). Here, we highlight care and justice as essential elements of sustainability (Gottschlich \& Bellina, 2016). Specifically, our understanding of sustainability is based on the concept of a care-centred economy that includes caring not only for people but also for "more than human worlds" (Gottschlich \& Katz, 2018, p. 84; see also Puig de la Bellacasa, 2017). To maintain and sustain the '(re)productivity of society and nature' (Biesecker \& Hofmeister, 2010), caring practices should be placed at the core of democracy (Tronto, 2013). From this standpoint, food democracy includes caring agricultural politics and practices, such as those that ensure soil 
(re)productivity and the wellbeing of animals. This is in stark contrast to the dominant corporate-driven agrifood system, characterized by injustice and externalization of the negative ecological and social effects of industrialized, high-input agriculture (e.g., deforestation, pollution, and health risks of pesticides). In this sense, Lang (1999, p. 217) and Petetin (2016, p. 1) distinguish between 'food democracy' and the current system of 'food control.'

A caring food democracy that seeks to overcome externalization has to be oriented towards intra- and intergenerational justice and achieving equal opportunities and dignified living conditions for all. This includes fair labour standards, protecting the health of producers and consumers, and addressing the inequitable distribution of negative social and environmental effects along the lines of class, gender, geography, or towards future generations (Ahlem \& Hammas, 2017; Brand \& Wissen, 2017; Mcintyre, Herren, Wakhungu, \& Watson, 2009). As a corollary of care and justice, the precautionary principle-incorporated in 1971 into the first environmental program of the German Federal Government $(1971$, p. 7)-is also essential to the substantive dimension of food democracy, in order to leave room for manoeuvre in decision-making for future generations. This goes against the dominant principles and practices of the present-day food system that tend to favour technological innovation, even to the extent of calling the precautionary principle into question (von Gleich \& Petschow, 2017).

In this article, our analysis of the interplay of procedural and substantive dimensions of food democracy is informed by a critical-emancipatory understanding of sustainability (Gottschlich, 2017a) which emphasizes the importance of care, justice and the precautionary principle. The question of what constitutes justice and care is always controversial. Therefore, we consider conflictsi.e., the public expression of contradictory ideas, interests, needs and practices-as central and productive elements of food democracy (and of democratic societynature relations in general) because they drive change and transformation (for another conceptual understanding of food democracy that embraces conflict and contestation as one dimension of food democracy, see also Bornemann and Weiland, 2019). We argue that conflictdriven forms of politics play a vital role in the creation of food democracy from a critical-emancipatory perspective (Gottschlich \& Hackfort, 2016; see also Lang, 1999, p. 217). A critical-emancipatory approach to sustainability calls certainties into question (Gottschlich \& Mölders, 2017 , p. 37). In conflicts over the future of agriculture, it is precisely such purported certainties (e.g., the positive effects of the industrialization of agriculture) that break down. These (and other) conflicts can be analysed taking different aspects into account, such as the focus of conflict, the actors involved, the type of conflict action, the conflict settlement, and the effects of the conflict (Bornemann \& Saretzki, 2018). As explained above, we consider it useful, in analysing conflicts like those over food democracy, to distinguish the substantive dimension from the procedural one. In our analysis, we consider the question of participation and the actors involved (e.g., movements), the settlement of conflicts by specific policies (e.g., coexistence policy) as well as the material and discursive effects of conflicts (e.g., the introduction of GMOs into ecosystems and the promotion of new kinds of agriculture and their different underlying views of nature).

\section{Empirical Case Study}

\subsection{GMO Policy in Germany and Poland}

At first sight, our research question seems to be of limited relevance to Europe, where the use of GMOs is relatively restricted compared to countries such as the United States, Brazil or Argentina. EU policy on GMOs envisages the coexistence, within Europe, of agricultural and food systems with and without GMOs. To date only two genetically modified (GM) crops have been cultivated commercially in Europe: MON810, a GM maize variety (currently cultivated primarily in Spain); and Amflora, a GM potato, which was cultivated commercially in a number of European countries between 2010 and 2011 (International Service for the Acquisition of Agri-biotech Applications, 2017). Apart from these commercial varieties, other GMOs have been released experimentally in Europe since the 1990s. European regulations also allow the import of animal feed containing GMOs. The EU's 'coexistence policy,' first set out in Directive 2001/18/EC on the deliberate release into the environment of genetically modified organisms (European Parliament \& Council of the EU, 2001), frames national-level GMO policy in both Germany and Poland. However, there are a number of differences between GMO policies in the two countries. In Germany, where the cultivation of GMOs is regulated by the Genetic Engineering Act (GenTG), MON810 was cultivated commercially between 2005 and 2008 (before being banned in April 2009), and Amflora in 2010 and 2011, in both cases accompanied by protests and conflicts in the localities where they were grown.

In Poland, the release of GMOs for commercial purposes and the marketing of genetically modified feed have both been prohibited (by the Seed Act and the Feed Act, respectively) since 2006. However, although the 2006 Polish Seed Act prohibited the inclusion of GM varieties in the Polish national seed registry and the marketing of such varieties, cultivation for farmers' own needs (e.g., to feed their own animals) and issues relating to the declaration of such cultivation were not covered by the legislation. These legal loopholes allowed farmers to acquire MON810 maize in neighbouring countries and cultivate it in their fields, particularly in southern Poland (Sulmowski, 2017, p. 212). In 2008, the Polish Supreme Chamber of Control ruled that regulations did not yet provide sufficient protection against the uncon- 
trolled spread of GMOs. However, this ruling did not immediately bring an end to the 'unofficial' cultivation of GM maize.

In both Germany and Poland, no GMOs have been cultivated (officially) in recent years, with the exception of some research-related experiments. Due to the intense conflicts they provoked, experimental releases of GMOs have also been suspended in Germany since 2014. One important pro-GMO player, the chemical company BASF, justified its withdrawal from the genetic engineering business in Germany in 2012 with reference to the lack of acceptance of the technology among the majority of consumers, farmers and politicians. In 2015, Germany and Poland opted out of future cultivation of MON810, taking advantage of a recent amendment to EU legislation (European Parliament \& Council of the EU, 2015) that makes it possible for member states to ban single GMO varieties, either because of their impacts on ecosystems, or in response to political conflicts. This possibility of opting out could be an option to strengthen food democracy (see Table 1). The decision by the European Court of Justice of 25 July 2018 to consider organisms produced by new breeding techniques (such as Genome Editing) as GMOs in the sense of the Release Directive 2001/18/EC (European Parliament \& Council the EU, 2001) represents a further success for the anti-GMO movement, which had fought for such a classification. However, in the future, both Germany and Poland could conceivably approve other GMOs or new breeding techniques for cultivation, in response to sustained lobbying by powerful interest groups, as well as a resurgence of calls by politicians and economists for existing regulations to be watered down. Thus, the use and handling of GMOs remains controversial.

\subsection{Methods}

We chose to study movements against GMOs in Germany and Poland as exemplars of West and East European countries. In this article, we discuss the extent to which the movements in the two countries have been successful in creating pathways for participation in the food system and towards the creation of alternatives. When we refer to conflicts surrounding GMOs, the different circumstances in the two countries should be kept in mind. However, our intention is not to draw comparisons between Germany and Poland, but rather to use data and results from these two different countries to develop a more comprehensive notion of food democracy. Our analysis draws on the work of the social-ecological research group "PoNa” ('Shaping Nature,' funded by the German Federal Ministry of Education and Research in the funding priority social-ecological research), which studied the relationship between nature and politics and how understandings of nature and politics are manifested in conflicts, including those over GMOs (Gottschlich \& Mölders, 2017). The empirical data consists of: (1) 14 qualitative interviews (Interviews 1-14) with opponents of GMOs (ten from Germany and four from Poland) involved in local, national or transnational conflicts; (2) transcripts of discussions in two focus groups with anti-GMO activists, including scientists and members of environmental non-governmental organisations and agricultural associations from Germany and Poland; (3) documents from both countries, such as transcripts of parliamentary debates and government regulations (laws, directives, etc.) published in the period 2004-2012; and (4) results of our iconographic analysis of flyers, posters and book covers shown in 2012 on the websites of the parties involved in the GMO debate (Gottschlich \& Sulmowski, 2017). This empirical data is supplemented by a review of relevant literature.

In our analysis, we combine a deductive with an inductive methodology. On the one hand, we apply our theoretical understanding of food democracy presented above to analyse anti-GMO movements in the two countries. On the other, we use the results of this analysis to develop and deepen our understanding of food democracy as manifested in conflicts surrounding GMOs.

\subsection{Movements against GMOs - Insights from Germany and Poland}

In the following section, GMO conflicts are considered as cases to address our research question regarding how conflicts over GMOs contribute to a democratization of society-nature relations.

Although protests against GMOs took place prior to the year 2000, social movements against them have grown significantly in Germany and Poland since the turn of the millennium. At the end of the 1990s, there were still few signs of public opposition to developments in the field of genetic engineering and researchers asked why politicization was not taking place (e.g., Hoffmann, 1997). One barrier to the growth of an anti-GMO movement was that GMO crops were still not being cultivated in Europe, so critiques remained on a conceptual level (Hoffmann, 1997). With the introduction of the coexistence policy in 2001 (analysed in detail below) and the abolition of the EU moratorium on the approval of GMOs in February 2004 (permitting GMO cultivation from 2005 onward), various processes were simultaneously set in motion. First, the focus of conflicts shifted to the level of decisions by individual farmers on whether to cultivate GMOs (cf. Friedrich, 2017; Vogt, 2007). Second, this meant that the debate regarding cultivation shifted to rural areas (cf. Friedrich, 2017; Vogt, 2007). Third, local conflicts that broke out in rural areas gave rise to national and transnational movements against the use and release of GMOs in agriculture (Seifert, 2013). Fourth, these movements criticized the narrow focus on individual decisions and economic impacts and succeeded in placing the issue of food production on the political agenda (Gottschlich, 2017b).

A key target of anti-GMO protests is the EU's policy of 'coexistence,' which allows the cultivation of GM 
crops, while envisioning that certain agricultural areas will remain 'GMO free.' This policy, introduced by the EU in 2001, thus attempts to skirt around the controversial question "GMOs-yes or no?" by answering "yes" and "no" at the same time. A notable effect of this policy has been to reduce the conflict over GMOs to the level of economic interests. The only impact of GMO use taken into consideration is the possible contamination of non-GM crops on neighbouring farms and consequent economic losses (since crops grown on these farms can no longer be marketed as GM-free). The policy stipulates that GMO growers should compensate for these economic losses in accordance with the polluter pays principle. The exclusive focus on economic issues is explicit in the legislation. For example, apart from legislation in a few German federal states covering distances between GM crops and nature reserves, liability and distance rules intended to mitigate impacts on 'GMO-free areas' apply only to areas used for the commercial cultivation of food. One interviewee whose private garden was affected by a registered area of genetically modified maize in a neighbouring field (Interview 2), described how he had asked the Federal Office of Consumer Protection to require the farmer to increase the distance between the GM maize and the maize in the garden, in accordance with the provisions of the GenTG. However, the application was rejected on the grounds that the Act only applied to commercial use; since maize in the garden was not grown commercially, it was not protected under the law (Interview 2). Opponents of GMOs fear that, given the systemic nature of the risks associated with the technology, 'coexistence' will make GMO-free agriculture impossible in the long term (Bethwell, Weith, \& Müller, 2012, p. 238; Stoppe-Ramadan \& Winter, 2010, p. 121; Winter \& Stoppe-Ramadan, 2012, p. 196). While some scientists hold that the distribution of pollen beyond directly adjacent property can be controlled, the effort required to achieve this through changes in agricultural practice and coordination among neighbours is very high. Moreover, such efforts are not always successful (Schimpf, 2008) and, even in cases where cross-pollination may seem unlikely on a theoretical level, the risk of the uncontrollable spread of transgenes is not manageable (Clark, 2004, p. 104).

The movement against GMOs has helped bring about political changes at a local, national and European level. Protesters have transformed public debate by carrying out a wide range of actions (see Table 1) that put pressure on political representatives and economic actors. The anti-GMO actors involved also participate in international groups that attempt to influence European and global political processes (Ansell, Maxwell, \& Sicurelli, 2006; Seifert, 2013, 2017).

An analysis of the actions and approaches of the antiGMO movement in Germany and Poland reveals that the anti-GMO movement uses criticism and direct action to resist the introduction of GMOs. At the same time, it engages in positive action to develop countervailing power structures that promote food democracy (see Section 4). These two forms of action are complementary; both contribute towards achieving the movement's overall goal of GM-free food production (see Table 1).

The systematization in Table 1 highlights the diversity of forms of both resistance and positive action within the anti-GMO movement. It also distinguishes among different 'levels' of action. These can be viewed as represent-

Table 1. Forms of resistance and positive action adopted by the anti-GMO movement.

\begin{tabular}{ll}
\hline Level of escalation & Resistance \\
\hline 1st Level & Protest as radical criticism \\
& e.g., flyers, information material, protest bike \\
& rides, telephone calls, tractor demonstrations, \\
& street protests, petitions, balloon and postcard \\
& campaigns, identification of 'crime scenes' \\
& (unregistered GMO fields in Poland), critiques \\
& exposing the economic bias in the coexistence \\
& principle
\end{tabular}

\section{2nd Level Institutional non-cooperation}

e.g., refusal to participate in round tables (justified with reference to the precautionary principle as set out in Art. 20a of the German constitution)

\begin{tabular}{ll}
\hline 3d Level Civil disobedience \\
e.g., open disregard for laws, for example \\
destruction of GMO crops in fields
\end{tabular}

\section{Positive action}

\section{Identification of alternatives}

e.g., alternative tillage methods and crop rotation, campaigns for diversity in seed supply

\section{Institutional innovation}

e.g., development of alternative information systems, such as the journal Unabhängige Bauernstimme (Independent Farmers' Voice) and the Informationsdienst Gentechnik (Genetic Engineering Information Service)

\section{Civil usurpation}

e.g., occupation of fields and pre-emptive sowing ('Gegensaat') of organic seeds, new alliances as a countervailing force for a 'bottom-up' agricultural policy

Source: Modified according to Gottschlich (2017b), in line with Ebert (1983). 
ing an 'escalation' of the conflict, in the sense that they are expressions of the increasing scope and ambition of anti-GMO protests.

At the first level of conflict, resistance takes the form of creative protests against GMO cultivation. Opposition to GMOs is expressed through the distribution of flyers, stickers and postcards and in various types of demonstrations. Many of these actions target those involved in the cultivation of GMOs, and are often organized by those directly affected, including farmers, gardeners, and beekeepers. One farmer reported that sometimes a phone call from another colleague was enough to dissuade a farmer who had registered an area for the cultivation of GMOs from actually doing so (Interview 3 ). In some cases, public protest in the form of bicycle tours from field to field prompted individual farmers to rethink their approach (Interview 4). In 2009 high-profile demonstrations carried out by anti-GMO activists in Poland on behalf of Greenpeace (Interview 11) identified 'GMO crime scenes' (i.e., the unofficial, unregistered GMO fields mentioned in Section 2). While the immediate aim of these actions is to dissuade farmers from cultivating GMOs, they also attempt to highlight the importance of GMOs as an issue of public concern. In this sense, activists call for a rejection of the principle of coexistence that, by enabling both the cultivation of GM crops and GM-free agriculture, devolves decision-making on GMOs to individual farmers. At this level, positive action by the anti-GMO movement focuses on promoting alternatives. Examples from our study include proposals for alternative farming methods and for diversity in seed supply.

At the second level, positive action focuses on creating alternative institutions such as information systems, newsletters or journals, while resistance is characterized by institutional non-cooperation. For example, in 2009, in response to increasing conflict, which had led to cultivation of MON810 being banned that year, the German ministries of agriculture and education launched a joint Round Table on Plant Genetics. The Round Table met a total of four times. However, most of its members were representatives of organizations in favour of GMOs. The chairman of the Federal Ecological Food Industry (Bund Ökologische Lebensmittelwirtschaft [BÖLW]) commented: "This round table is...an extremely one-sided event" (quoted in Schmid, 2010, authors' translation). At the third meeting in June 2010, all participating environmental NGOs (Deutscher Naturschutzring [DNR], BÖLW, Naturschutzbund Deutschland e.V. [NABU], Bund für Umwelt und Naturschutz Deutschland [BUND], and Greenpeace) announced their decision to withdraw from the round table. They justified their decision by stating that the answers received from the Federal Ministry of Education and Research (BMBF, 2010) to their "NinePoint Catalogue for Ecological Safety Research," submitted before the previous meeting, were unacceptable in both content and form. The NGOs had substantiated their demands in this "catalogue" with scholarly citations, while the BMBF's reply contained claims that were not supported by a single scholarly source (DNR, NABU, BÖLW, \& Vereinigung deutscher Wissenschaftler, 2010, p. 1). The NGOs also responded publicly to the BMBF's assertion that it is "not the task of the state to evaluate the usefulness or desirability of non-hazardous social action, such as research into and use of green genetic technology" (BMBF, 2010, p. 8). The NGOs countered that, according to Article 20a of the German constitution (Federal Republic of Germany, 2019), it is indeed the task of the state to protect the general public against unjustifiable risks and dangers. The precautionary principle and the orientation towards sustainability are laid down in law and should be complied with.

At the third level of escalation in the conflict, civil disobedience in the form of what protesters referred to as "field liberations" (which took place in Germany but not in Poland) is combined with "civil usurpation," i.e., measures to actively promote and implement new forms of agricultural production by sowing organic seeds. At the same time, new alliances provide the impetus for setting up counter-structures for the formulation and implementation of an alternative vision for agriculture. These include alliances that bring together producers and consumers, organic and conventional farmers, and a range of other actors and associations (farmers' associations, nature and consumer protection organisations, political parties and churches). These alliances have the potential to build bridges across long-established political divides. For example, one activist from Poland (Interview 11) reported that she was surprised to see who had supported the protest against the use of GMOs and described how the development of mutual understanding helped open up new possibilities and overcome old prejudices. In her opinion, the campaigns had the potential to contribute to the further development of Polish civil society by overcoming the silence of the media on important issues such as GMOs and bringing citizens and politicians into contact. GMO to nie to, the relatively young alliance against GMOs in Poland, called on people to contact their local MPs. The activist commented that, for many people, this was their first direct contact with politicians and their first opportunity to remind them that it was their job to represent the interests of the Polish people (Interview 11).

\section{Discussion}

How do the empirical findings reported in the previous section contribute to an understanding of how conflicts over GMOs can contribute to democratizing societynature relations and therefore enable and deepen food democracy? We first discuss some negative effects of the policy of coexistence and then highlight different aspects of the democratizing role played by the movements against GMOs.

The current policy of 'coexistence,' which on the surface appears to be a means of avoiding conflict, has in fact exacerbated conflict, while at the same time creating obstacles to the development of food democracy. 
In the short-term, coexistence policy exacerbates asymmetries between industrialized agriculture and alternative agricultural practices, especially in the regions where GMOs are grown (Binimelis, 2008). The use of GMOs in agriculture could be especially detrimental to organic farming, which is expected to be free of GMOs. Contamination with transgenes would mean that products could no longer be labelled as organic and could only be sold at lower prices. This would not only cause economic losses to individual farmers, but also loss of consumer confidence in organic labels. Similarly, for beekeepers, the presence of traces of GMOs in their honey would imply a huge economic loss. In reality, 'coexistence' only guarantees the freedom of choice for GMO-based agriculture, while impeding development of other, more sustainable types of agriculture, such as organic farming.

In the long run it is not possible to avoid contamination in an open system and, once GMOs have been introduced into an agricultural system, it is questionable whether any part of that system can remain truly GMOfree. Given that there is already empirical evidence for the spread of transgenes beyond the areas and regions in which GM crops are cultivated, coexistence cannot be considered a long-term option (Altieri, 2005; Winter, 2009). The disappearance of GMO-free agriculture will favour the prevailing model of industrialized agriculture (cf. Binimelis, Monterroso, \& Vilella, 2010, p. 90), consolidating the processes of market concentration and monopolization (cf. Howard, 2009), as exemplified by the merger between Monsanto and Bayer in 2018.

Thus, by granting farmers individual freedom of choice to decide whether to cultivate GM crops, the policy externalizes the negative effects of GM-based agriculture and denies citizens the freedom to democratically decide on the future of food systems. For example, according to the German federal government, in order to achieve certain sustainability goals, the share of organic agriculture should increase to at least $20 \%$ by 2050 (German Federal Ministry of Food and Agriculture, 2019). Clearly in a democratized food system the role of organic agriculture (and other alternatives to industrialized agriculture) should be the subject of public debate. Coexistence policy, if widely applied, would unilaterally cut off these alternative avenues towards sustainable food production, and is thus contrary to the principles of both procedural and substantive food democracy.

While potentially making GMO-free agriculture impossible, coexistence policy is designed not only to shut down debate around the key question if GMOs should be used at all, but also to prevent public examination of the societal and socio-ecological impacts of GMO cultivation. Assessment of risks, narrowly defined as technological risks, is carried out by experts, away from the public gaze. This reflects a technocratic interpretation of the precautionary principle, in which non-technical and normative aspects are considered irrelevant to risk assessment. This technocratic approach favours the bureaucra- tization of coexistence policy in a way that excludes participatory democracy. It denies a voice to the broad majority of consumers who are against the use of GMOs in food production (Growth from Knowledge, 2018).

Regarding the social effects of GMO policy, in some cases the introduction of GMOs led to fruitful processes of politicization, for example in the form of discussions regarding the future of agriculture in the regions where GMOs were grown. More often, however, the implementation of coexistence policy led to the personalization of controversies over economic problems and ecological risks associated with the introduction of GMOs. These controversies were difficult to mediate as political and personal aspects were interwoven (Friedrich, 2017). Coexistence has not given rise to conflict in the sense of broad democratic discussion processes but rather to an individualization and economization of the problem, at the same time as discouraging public debate on wider issues relating to the future of food systems.

Our findings further suggest that top-down participatory procedures like the round tables described above are insufficient, in themselves, for enabling progress towards food democracy. In this case, it appears that the terms of reference for the round tables were designed to exclude in-depth debate and maintain the status quo. Whether or not this was the intention, the views of the members of the round table regarding the topic under discussion, and their expectations regarding the use of participatory procedures to reach agreement, were so different that there could be no consensus.

In contrast to these negative impacts of coexistence policy, our findings indicate that the anti-GMO movements play a democratizing role. As shown in Section 3.3, there are several starting points leading to the development of a range of emancipatory political concepts and practices of resistance, embodying alternatives to procedural and substantive dimensions of the status quo.

The anti-GMO movement challenges the fundamental presupposition of coexistence policy that GMO cultivation is a matter of individual choice. Protests 'in the field' assert the right of neighbours, communities and wider society to have a say in whether or not GM crops are planted in a particular location. Protests against GMOs are combined with promotion of alternative agricultural technologies. By presenting a positive vision for an alternative agriculture future, protesters highlight the fundamental flaw of the coexistence policy: that the 'compromise' it offers is illusory, since it cannot in fact guarantee the continued existence of non-GMO agriculture. Protesters argue that debates about the future of agriculture should not be foreclosed by the use of these risky technologies. Thus, it becomes clear that, with regard to its substantive dimension, food democracy depends on adoption of the precautionary principle as a paradigm for agricultural (and other environmental) policy.

The movement refuses to be co-opted by top-down processes designed to maintain the status quo. It re- 
sponds by setting up alternative, transformative processes that aim to broaden participation and to encourage a politicization of the debate. Activists of the antiGMO movement combine individual-level, consumeroriented approaches (e.g., boycotts) with demands for a policy environment that guarantees the continued existence of GMO-free agriculture and availability of GMOfree food. This approach recognizes that consumers are key actors in food production systems but insists that consumer responsibility cannot and should not replace state regulation as a guardian of sustainability. Dual strategies such as these are a central characteristic of the movement: Anti-GMO activists combine their critique of current policies with both demands for greater say in decision-making and a vision for an alternative agricultural future. In these actions, the procedural and substantive dimensions of food democracy are intertwined.

Anti-GMO movements challenge the technocratic interpretation of the precautionary principle. This is a key contribution since precaution is a central element of a care-centred understanding of sustainability. From this perspective, precaution encompasses more than risk assessment. In particular, its orientation towards intergenerational justice requires that regulatory frameworks should leave choices open to future generations, even if this means forgoing the use of a technology that offers short-term benefits or that offers benefits only to a segment of the population.

The anti-GMO movement builds alliances for the discussion and implementation of alternative futures for agriculture and food systems. In Germany, noncommercial actors whose interests are ignored by the GenTG organized protests such as demonstrations and even acts of civil disobedience. All these actions contributed to the procedural dimension of food democracy by opening up political spaces for negotiation regarding the (socially desirable) future of nature and agriculture. Although the cultivation of GMOs has not been a concern for a while, the movement has continued to advocate for broad participation of both producers and consumers in determining the future of food systems, for example through large demonstrations organized by the alliance "Meine Landwirtschaft/Wir haben Agrarindustrie satt" (My agriculture/we're fed up with agro-industry) in Berlin since 2011.

\section{Conclusion and Outlook}

This study has analysed some of the conflicts surrounding the use of GMOs and how the movements against GMOs in Germany and Poland contribute to a democratization of society-nature relations. The results show that the EU's policy of coexistence has not only failed in its attempt to end the conflict over the use of GMOs, but has also provoked new conflicts, leading to an entrenchment of opposing views rather than a constructive debate on agricultural futures. At the same time, the movements against GMOs have opened up a space of negotiation and struggle about agricultural futures, including not only alternative ideas, but also practices.

Pro-GMO policies are not anti-democratic and antiGMO policies are not pro-democratic per se. However, our research suggests that pro-GMO policies are incompatible with both the substantive and procedural dimensions of food democracy. Any use of GMOs in agriculture appears to be in contradiction to the concept of care and the precautionary principle, which are central components of the substantive dimension of food democracy. Consideration of the potential interests of future generations and the need to leave options open for different modes of agricultural production, including organic agriculture, precludes the use of technologies such as GMOs that may change both ecosystems and socio-economic systems irreversibly.

Conversely, anti-GMO movements contribute to democratizing society-nature relations by challenging the individualization of conflict and the externalization of social and environmental impacts that are the result of giving individual farmers the "freedom to choose" whether to use GMOs. These movements play a democratizing role in $\mathrm{GMO}$ conflicts and, to the extent that they are successful, also contribute to the substantive dimension food democracy. This is illustrated by three positive outcomes of anti-GMO protests (described above in Section 3.1): (1) The new EU policy which gives individual member states the possibility of opting out of GMO cultivation is, at least in part, a recognition of the multifaceted nature of opposition to GMOs-it acknowledges the need for policy makers to listen to the voices arguing that policy should take into account long-term socioecological interests (and not only short-term economic ones); (2) BASF's withdrawal from the genetic engineering business in Germany is evidence of the potential of public opposition to alter the trajectory of agricultural development; and (3) the decision that new breeding techniques such as genome editing should be covered by the same legislation as GMOs in the EU corresponds to a key demand of anti-GMO activists.

Concerning the concept of food democracy that we have introduced above, it becomes clear that although the procedural and substantive dimensions of conflicts around food democracy can be separated analytically, in practice they are intertwined. This is because participatory procedures are not neutral. Powerful interests promote top-down forms of participation because the latter provide a better chance of keeping control of the process and determining its outcomes. Conversely, those opposed to the status quo struggle to gain recognition for bottom-up forms of participation that, by their very nature, challenge vested interests.

Food democracy should both fulfil the needs of people and sustain nature. Achieving this requires decisions about how societies organize their agricultural production to ensure adherence to the principles of care and justice, in both process and outcomes. From this perspective, conflicts over GMOs are about much more than the 
use of a specific technology. The substantive dimension of food democracy is broader and more complex than the question: GMOs, yes or no? Other substantive issues need to be considered, especially in relation to the compatibility of agricultural (and associated) practices with the principle of care towards all those involved in the production and consumption of food (e.g., labour standards or the health of producers and consumers). Moreover, food democracy should guarantee the (re)productivity of society and agriculture in the future, thus taking inter- as well as intragenerational justice into account. There is no single type of agriculture that does this, but a range of alternatives are emerging from a broad movement that encompasses many forms of small-scale farming practices, united by their commitment to food sovereignty (such as community urban gardening and other agro-ecological forms of food production).

The movement against GMOs has helped to initiate a wider debate regarding the role that technological innovation can play in achieving a democratic and sustainable food production. Developments in new breeding techniques highlight the continuing relevance-and increasing complexity - of these issues. In particular, new breeding techniques once again raise the question of whether coexistence is a viable model for the future. At present it is difficult to monitor the spread of genetic changes introduced by new breeding techniques. This raises a new question: Is it even possible to regulate the conflict on an economic level through a polluter pays principle, as the policy of coexistence proposes, if the source and even the occurrence of pollution are difficult to verify? Here again, the movements against GMOs are helping to politicize the debate by broadening it out into a wider discussion about food democracy and the future of agriculture. At the same time such debates have given rise to new coalitions that are different from those in previous conflicts about GMOs. For example, sections of the German Green Party, that previously opposed GMOs, are now ambivalent about the use of new breeding techniques. Both opponents and proponents of new breeding techniques justify their positions with reference to sustainability. This serves as a reminder that sustainability itself cannot be defined in technical terms, but is always an aspiration and an ongoing effort, obliged to adapt to everchanging circumstances. It highlights the importance of a critical-emancipatory understanding of sustainability in providing an analytical and normative framework for food democracy; one that incorporates practices of resistance, continuous public debate and broad participation in decision-making and is guided by the principles of care, precaution, and intra- and intergenerational justice.

\section{Acknowledgments}

The research was (partly) conducted by the research group "PoNa-Shaping Nature: Policy, Politics and Polity" at Leuphana University of Lüneburg, Germany, and supported by the German BMBF (PoNa 01UU0903). We thank the BMBF for its generous funding. We also thank the editors and three reviewers for their specific and careful comments to improve the text and Gudrun Harms for her support in the preparation of the references. Last but not least, we are very grateful to Andrew Halliday for his language editing support.

\section{Conflict of Interests}

The authors declare no conflict of interests.

\section{References}

Ahlem, Z., \& Hammas, M. A. (2017). Organic farming. A path of sustainable development. International Journal of Economics \& Management Sciences, 6(5), 456.

Altieri, M. A. (2005). The myth of coexistence: Why transgenic crops are not compatible with agroecologically based systems of production. Bulletin of Science, Technology \& Society, 25(4), 361-371.

Ansell, C., Maxwell, R., \& Sicurelli, D. (2006). Protesting food: NGOs and political mobilization in Europe. In C. Ansell \& D. Vogel (Eds.), What's the beef? The contested governance of European food safety (pp. 97-122). Cambridge, MA: MIT Press.

Barber, B. (2003). Strong democracy. Participatory politics for a new age. Berkeley, CA, Los Angeles, CA, and London: University of California Press. (Original work published 1984)

Behringer, J., \& Feindt, P. H. (2019). How shall we judge agri-food governance? Legitimacy constructions in food democracy and co-regulation discourses. Politics and Governance, 7(4), 119-130.

Bethwell, C., Weith, T., \& Müller, K. (2012). StakeholderInteraktionen regional: Risikogovernance-Entwicklung eines Kommunikationsprozesses zum Umgang mit dem Anbau von GVO in der Region MärkischOderland [Regional stakeholder interactions: Risk governance-Development of a communication process for dealing with the cultivation of GMOs in the Märkisch-Oderland region]. In B. Breckling, G. Schmidt, \& W. Schröder (Eds.), GeneRisk. Systematische Risiken der Gentechnik: Analyse von Umweltwirkungen gentechnisch veränderter Organismen in der Landwirtschaft [GeneRisk. Systematic risks of genetic engineering: Analysis of environmental impacts of genetically modified organisms in agriculture] (pp. 237-260). Berlin and Heidelberg: Springer.

Biesecker, A., \& Hofmeister, S. (2010). Focus: (Re)productivity. Sustainable relations both between society and nature and between the genders. Ecological Economics, 69(8), 1703-1711.

Binimelis, R. (2008). Coexistence of plants and coexistence of farmers. Is an individual choice possible? Journal of Agricultural and Environmental Ethics, 21(5), 437-458.

Binimelis, R., Monterroso, I., \& Vilella, M. (2010). Is there any room for alternatives? Socio-economic implica- 
tions of GMOs cultivation at large-scale: Case study in Spain. In B. Breckling \& R. Verhoeven (Eds.), Largearea effects of GM-crop cultivation. Proceedings of the second GMLS-conference 2010 in Bremen (Theorie in der Ökologie Vol. 16) (pp. 89-90). Frankfurt a. M.: Peter Lang.

Bornemann, B., \& Saretzki, T. (2018). Konfliktfeldanalyse: das Beispiel "Fracking" in Deutschland [Analysis of areas of conflict: The example of fracking in Germany]. In L. Holstenkamp \& J. Radtke (Eds.), Handbuch Energiewende und Partizipation [Handbook of energy transition and participation] (pp. 563-581). Wiesbaden: Springer.

Bornemann, B., \& Weiland, S. (2019). Empowering people: Democratising the food system? Exploring the democratic potential of food-related empowerment forms. Politics and Governance, 7(4), 105-118.

Brand, U., \& Wissen, M. (2017). The imperial mode of living. In C. Spash (Ed.), The Routledge handbook of ecological economics: Nature and society (pp. 152-161). London: Routledge.

Carlson, J., \& Chapell, M. J. (2015). Deepening food democracy. Minneapolis, MN: Institute for Agriculture and Trade Policy. Retrieved from https://www. iatp.org/sites/default/files/2015_01_06_ Agrodemocracy_JC_JC_f_0.pdf

Clark, E. A. (2004). GM crops are not containable. In B. Breckling \& R. Verhoeven (Eds.), Risk hazard damage: Specification of criteria to assess environmental impact of genetically modified organisms (Vol. 1, pp. 91-108). Bonn-Bad Godesberg: Federal Agency for Nature Conservation.

Deutscher Naturschutzring, Naturschutzbund Deutschland e.V., Bund ökologische Lebensmittelwirtschaft, Vereinigung deutscher Wissenschaftler. (2010). Reaktion auf die Anmerkungen des BMBF zum 9Punktepapier der Verbände DNR, NABU, BÖLW und $V D W$ [Reaction to the comments of the BMBF on the 9-point paper of the associations DNR, NABU, BÖLW and VDW]. Retrieved from http://www.nabu.de/ downloads/Reaktion_auf_BMBF-Anmerkungen.pdf

Ebert, T. (1983). Gewaltfreier Aufstand: Alternative zum Bürgerkrieg [Nonviolent uprising: Alternative to civil war]. Waldkirch: Waldkircher Verlagsgesellschaft $\mathrm{mbH}$.

European Parliament, \& Council of the European Union. (2001). Directive 2001/18/EC of the European Parliament and of the Council of 12 March 2001 on the deliberate release into the environment of genetically modified organisms and repealing Council Directive 90/220/EEC. Luxembourg: Publications Office of the EU.

European Parliament, \& Council the European Union. (2015). Directive (EU) 2015/412 of the European Parliament and of the Council of 11 March 2015 amending Directive 2001/18/EC as regards the possibility for the member states to restrict or prohibit the cultivation of genetically modified organisms (GMOs) in their territory. Luxembourg: Publications Office of the EU. Federal Republic of Germany. (2019). Grundgesetz für die Bundesrepublik Deutschland in der im Bundesgesetzblatt Teil III, Gliederungsnummer 100-1, veröffentlichten bereinigten Fassung, das zuletzt durch Artikel 1 des Gesetzes vom 28. März 2019 (BGBI. I S.404) geändert worden ist [Basic law for the Federal Republic of Germany in the adjusted version published in the Federal Law Gazette Part III, section 100-1, which was last amended by Article 1 of the Law of $28 \mathrm{March}$ 2019 (BGBI. I p. 404)]. Retrieved from https://www. gesetze-im-internet.de/gg/GG.pdf

Fraser, N. (2009). Scales of justice: Reimagining political space in a globalizing world. New York, NY: Columbia University Press.

Friedrich, B. (2015). Das Konfliktfeld gesellschaftliche Naturverhältnisse am Beispiel von Agro-Gentechnik. Eine Fallstudie in den Landkreisen Kitzingen, LüchowDannenberg und Oberhavel [Agro-genetic engineering as an area of conflict over human-nature relations: Case studies of rural districts in Germany] (Doctoral dissertation). Leuphana University of Lüneburg, Lüneburg, Germany.

Friedrich, B. (2017). “Der ganze Landkreis komplett in Aufruhr": Konflikte um Agro-Gentechnik 2005 bis 2009-Theoretische Perspektiven und empirische Ergebnisse ["The whole district completely in uproar": Conflicts over genetic engineering for agriculture from 2005 to 2009-Theoretical perspectives and empirical results]. Zeitschrift für Agrargeschichte und Agrarsoziologie (ZAA), 65(1), 75-89.

German Federal Government. (1971). Umweltprogramm [Environmental programme]. Bonn: German Government.

German Federal Ministry of Education and Research. (2010). Anmerkungen des Bundesministeriums für Bildung und Forschung zum "9-Punkte-Katalog für eine ökologische Risikoforschung" der Umweltverbände BÖLW, BUND, DNR, Greenpeace, NABU und VDW [Remarks of the Federal Ministry of Education and Research on the "9-point catalogue for ecological risk research" of the environmental associations BÖLW, BUND, DNR, Greenpeace, NABU and VDW]. Berlin: German Federal Ministry of Education and Research. Retrieved from http://www.nabu.de/ downloads/Anmerkungen_BMBF.pdf

German Federal Ministry of Food and Agriculture. (2019). Zukunftsstrategie ökologischer Landbau. Impulse für mehr Nachhaltigkeit in Deutschland [Future strategy for organic farming: Moves towards more sustainability in Germany]. Berlin: German Federal Ministry of Food and Agriculture. Retrieved from https://www. bmel.de/SharedDocs/Downloads/Broschueren/ Zukunftsstrategie-oekologischer-Landbau.pdf; jsessionid=4527C639514818768CB4A5DC5821DBFD. 1_cid288?_blob=publicationFile

Gottschlich, D. (2017a). Kommende Nachhaltigkeit. Nachhaltige Entwicklung aus kritisch-emanzipa- 
torischer Perspektive [Sustainability to come: Sustainable development from a critical emancipatory perspective]. Baden-Baden: Nomos.

Gottschlich, D. (2017b). Demokratisierung gesellschaftlicher Naturverhältnisse durch Widerstand und Gegenmacht: Die Bewegung gegen Agro-Gentechnik als Teil einer neuen Demokratiebewegung [Democratization of society-nature relations through resistance and countervailing power: The movement against biotechnology in agriculture as part of a new democracy movement]. In D. Gottschlich \& T. Mölders (Eds.), Politiken der Naturgestaltung: Ländliche Entwicklung und Agro-Gentechnik zwischen Kritik und Vision [Shaping nature: Policy, politics and polity. Rural development and biotechnology in agriculture between criticism and vision] (pp. 193-216). Wiesbaden: Springer.

Gottschlich, D., \& Bellina, L. (2016). Justice and care: Critical emancipatory contributions to conceptualizing sustainable development. Agriculture and $\mathrm{Hu}$ man Values (AHV), 33(4), 941-953.

Gottschlich, D., \& Hackfort, S. K. (2016). Zur Demokratisierung gesellschaftlicher Naturverhältnisse: Und warum die Perspektiven der Politischen Ökologie dafür unverzichtbar sind [On the democratization of society-nature-relations: And why the perspectives of political ecology are indispensable for this]. PVS Politische Vierteljahresschrift. Zeitschrift der Deutschen Vereinigung für Politische Wissenschaft, 57(2), 300-322.

Gottschlich, D., \& Katz, C. (2018). Caring with natur/s: Care als Transformationspraxis für die Gestaltung gesellschaftlicher Naturverhältnisse [Caring with nature/s: Care as transformative practice for shaping society-nature relations]. In W. Waidelich \& $\mathrm{M}$. Baumgarten (Eds.), Um-Care zum Leben: Ökonomische, theologische, ethische und ökologische Aspekte von Sorgearbeit [Caring back to life: Economic, theological, ethical and ecological aspects of care work] (pp. 83-105). Hamburg: VSA.

Gottschlich, D., \& Mölders, T. (Eds.). (2017). Politiken der Naturgestaltung. Ländliche Entwicklung und AgroGentechnik zwischen Kritik und Vision [Shaping nature: Policy, politics and polity. Rural development and biotechnology in agriculture between criticism and vision]. Wiesbaden: Springer.

Gottschlich, D., \& Sulmowski, Y. (2017). Reflections on the plurality of transdisciplinary processes in the research project PoNa: Dialogue with practitioners on picture-discourse-analysis as an example. In M. Padmanabhan (Ed.), Transdisciplinarity for sustainability (pp. 85-110). London: Routledge.

Gottschlich, D., Sulmowski, J. A., \& Friedrich, B. (2017). Fazit zum Politikfeld Agro-Gentechnik: Umkämpfte Naturgestaltung, umkämpfte Politikgestaltung [Conflicts over agro-genetic engineering: ConclusionContested processes of shaping nature and policy]. In D. Gottschlich \& T. Mölders (Eds.), Politiken der
Naturgestaltung: Ländliche Entwicklung und AgroGentechnik zwischen Kritik und Vision [Shaping nature: Policy, politics and polity. Rural development and biotechnology in agriculture between criticism and vision] (pp. 217-224). Wiesbaden: Springer.

Growth from Knowledge. (2018). Low-sugar and GMOfree are top factors when deciding what to eat or drink. Growth from Knowledge. Retrieved from http://www.gfk.com/global-studies/global-studiesdecision-factors-on-what-to-eat-and-drink/

Haerlin, B. (2013). “Good Food-Good Farming!” Eine neue europäische Demokratiebewegung entsteht ["Good Food-Good Farming!" A new European movement for democracy is emerging]. In AgrarBündnis e. V. (Eds.), Der kritische Agrarbericht 2013. Schwerpunkt: Agrarreform [The critical agricultural report 2013. Focus: Agricultural reform] (pp. 45-48). Konstanz and Hamm: ABL Bauernblatt Verlags-GmbH.

Hassanein, N. (2003). Practicing food democracy: A pragmatic politics of transformation. Journal of Rural Studies, 19(1), 77-86.

Hoffmann, D. (1997). Barrieren für eine Anti-GenBewegung. Entwicklung und Struktur des kollektiven Widerstands gegen Forschungs- und Anwendungsbereiche der Gentechnologie in der Bundesrepublik Deutschland [Barriers to an anti-GMO movement: Development and structure of collective resistance against investigation and application of genetic engineering in the Federal Republic of Germany]. In R. Martinsen (Ed.), Politik und Biotechnologie: Die Zumutung der Zukunft [Politics and biotechnology: The imposition of the future] (pp. 235-255). BadenBaden: Nomos.

Howard, P. H. (2009). Visualizing consolidation in the global seed industry: 1996-2008. Sustainability, 1(4), 1266-1287.

International Service for the Acquisition of Agri-biotech Applications. (2017). Global status of commercialized biotech/GM crops in 2017 (Brief 53). Ithaca, NY: International Service for the Acquisition of Agribiotech Applications. Retrieved from http://www. isaaa.org/resources/publications/briefs/53/ download/isaaa-brief-53-2017.pdf

Lang, T. (1999). Food policy for the 21st century: Can it be both radical and reasonable? In M. Koc, R. MacRae, L. J. A. Mougeot, \& J. Welsh (Eds.), For hunger-proof cities: Sustainable urban food systems (pp. 216-224). Ottawa: International Development Research Centre.

Levidow, L., \& Carr, S. (2010). GM food on trial: Testing European democracy. New York, NY: Routledge.

Loos, J., Abson, D., Chapell, M., Hanspach, J., Mikulack, F., Tichit, M., \& Fischer, J. (2014). Putting meaning back into "sustainable intensification." Frontiers in Ecology and the Environment, 12(6), 356-361.

Mcintyre, B. R., Herren, H., Wakhungu, J., \& Watson, R. T. (Eds.). (2009). Agriculture at a crossroads: The global report (International Assessment of Agricul- 
tural Knowledge, Science and Technology for Development Report). Washington, DC: Island Press. Retrieved from http://wedocs.unep.org/bitstream/ handle/20.500.11822/8590/Agriculture_at_a_ Crossroads_Global_Report.pdf?sequence $=\overline{3}$ \&isAllowed=y

McMichael, P. (2014). Historicizing food sovereignty. The Journal of Peasant Studies, 41(6), 933-957.

Petetin, L. (2016). Food democracy in food systems. In P. Thompson \& D. Kaplan (Eds.), Encyclopedia of food and agricultural ethics. Dordrecht: Springer. Retrieved from https://link.springer.com/content/pdf/ 10.1007\%2F978-94-007-6167-4_548-1.pdf

Puig de la Bellacasa, M. (2017). Matters of care: Speculative ethics in more than human worlds. Minneapolis, MN: Minnesota University Press.

Schimpf, M. (2008). Koexistenz im landwirtschaftlichen Alltag: Bericht zur Verbreitung von gentechnisch verändertem Material durch Landmaschinen [Coexistence in everyday agricultural life: Report on the dissemination of genetically modified material by agricultural machinery]. Hamm: AbL.

Schmid, T. (2010). Runder Tisch Pflanzengenetik. Naturschützer bleiben zuhause [Round table on plant genetics. Nature conservationists stay at home]. Taz. Retrieved from http://www.taz.de/!55336

Seifert, F. (2013). Transnational diffusion of a high-cost protest method: Open field destructions in France, Germany and Spain. Interface: A Journal for and about Social Movements, 5(2), 213-239.

Seifert, F. (2017). Measuring the Europeanization of the anti-GM movement: Evidence from five EU Countries. Mobilization: An International Quarterly, 22(3), 363-383.

Stoppe-Ramadan, S., \& Winter, G. (2010). EU and German law on coexistence: Individual and systemic solutions and their compatibility with property rights. In B. Breckling \& R. Verhoeven (Eds.), Large-area effects of GM-crop cultivation. Proceedings of the second GMLSconference 2010 in Bremen (Theorie in der Ökologie Vol. 16) (pp. 121-124). Frankfurt a. M.: Peter Lang. Sulmowski, J. (2017). Kontroverse Praktiken einer öf- fentlichen Kontroverse: Schließungen von Aushandlungsräumen in der Agro-Gentechnik-Debatte in Polen. [Controversial practices in a public controversy: Closing off negotiating space in the debate on agro-genetic engineering]. Wiesbaden: Springer.

Tronto, J. C. (2013). Caring democracy. Markets, equality, and justice. New York, NY: New York University Press.

Vogt, M. (2007). GenEthik zwischen Interessens- und Überzeugungskonflikten. [Genetic ethics between conflicts of interests and convictions]. In B. Köstner, M. Vogt, \& B. van Saan-Klein (Eds.), Agro-Gentechnik im ländlichen Raum: Potenziale, Konflikte, Perspektiven [Agro-genetic engineering in rural areas: Potentials, conflicts, perspectives] (pp. 21-40). Dettelbach: J.H. Röll Verlag.

von Gleich, A., \& Petschow, U. (2017). Aktuelle Diskussion um die Einführung eines Innovationsprinzips und das Verhältnis zum Vorsorgeprinzip. Kurzstudie [Current discussion on the introduction of an innovation principle and how it relates to the precautionary principle. Short survey]. Berlin: IÖW Institut für ökologische Wirtschaftsforschung.

Winter, G. (2009). Pro und contra Gentechnik: ein Vorschlag zur Güte [For and against genetic engineering: A conciliatory proposition]. Zeitschrift für Umweltrecht, 20(5), 225-226.

Winter, G., \& Stoppe-Ramadan, S. (2012). Koexistenz gentechnikfreier und gentechniknutzender Landwirtschaft: Von individueller zu systemischer Konfliktlösung [Coexistence of GMO-free and GMO-based agriculture: From individual to systemic conflict resolution]. In B. Breckling, G. Schmidt, \& W. Schröder (Eds.), GeneRisk-Systematische Risiken der Gentechnik: Analyse von Umweltwirkungen gentechnisch veränderter Organismen in der Landwirtschaft [GeneRisk-Systemic risks of genetic engineering: Analysis of environmental effects of GMO in agriculture] (pp. 185-206). Berlin and Heidelberg: Springer Verlag.

Wittman, H. (2011). Food sovereignty: A new rights framework for food and nature? Environment and Society: Advances in Research, 2(1), 87-105.

\section{About the Authors}

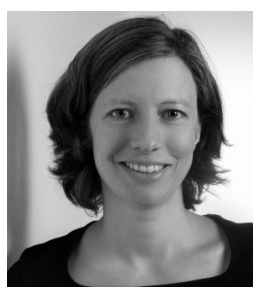

Beate Friedrich is an Environmental and Sustainability Scientist, currently teaching and researching at the Faculty of Sustainability at Leuphana University of Lüneburg, Germany, and researching as a Visiting Research Fellow at SPRU-Science Policy Research Unit, University of Sussex, Brighton, UK. Her research interests include social-ecological research, nature-gender relations, conflicts over plant breeding technologies, agricultural biotechnology and genetic engineering, sustainable regional development, conflict sociology, urban/rural sociology, and social movements.

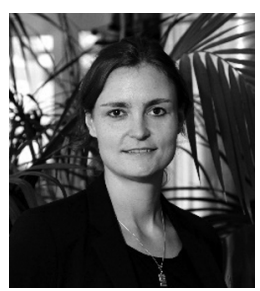

Sarah Hackfort is a Political Scientist and Head of Research for Sustainability and Transformation at the Institute of Future Studies and Technology Assessment (IZT) in Berlin. She is also Co-Leader of the research group 'BioMaterialities' at the Department of Agriculture and Food Policy at HumboldtUniversität zu Berlin. Her research interests include social-ecological transformation processes, agriculture and technologies from a political ecology and feminist perspective. 


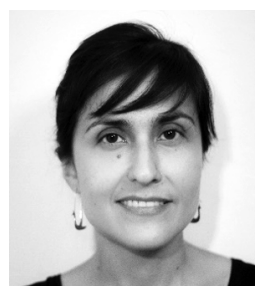

Miriam Boyer is currently Co-Leader of the research group 'BioMaterialities' at the Department of Agriculture and Food Policy at Humboldt-Universität zu Berlin. Her research interests include societygender relations, theoretical approaches to materiality and nature in the social sciences and the history and development of biotechnologies.

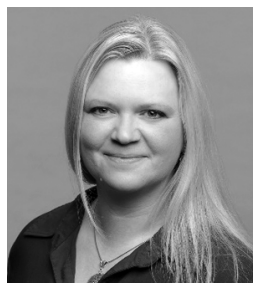

Daniela Gottschlich is a Political and Sustainability Scientist. Following interim professorships at Humboldt-Universität zu Berlin, and the Universities of Hamburg and Trier, she currently works at the Institute of Diversity, Nature, Gender and Sustainability in Lüneburg, where she leads the project "Ecology and Right-Wing Extremism." Her research interests include political and social ecology, democratization of societal relations, feminist economics, social movements and their contributions to everyday utopias. 